\title{
Analisis Spasial Kasus Malaria di Kabupaten Banyumas Tahun 2009-2018
}

\author{
Spatial analysis of Malaria in Banyumas Regency 2009-2018
}

\author{
Destika Dhaniasri, Dwi Sarwani Sri Rejeki*, Setyowati Raharjo \\ Jurusan Kesehatan Masyarakat, Fakultas Ilmu-Ilmu Kesehatan, Universitas Jenderal Soedirman \\ Jalan dr. Soeparno Kampus Karangwangkal, Purwokerto, Jawa Tengah, Indonesia \\ Corresponding author: Dwi Sarwani Sri Rejeki \\ *E_mail: dwi.rejeki@unsoed.ac.id
}

Received date: 24-08-2020, Revised date: 06-11-2020, Accepted date: 17-11-2020

\begin{abstract}
ABSTRAK
Malaria masih menjadi salah satu masalah kesehatan di Kabupaten Banyumas. Informasi spasial dapat digunakan sebagai salah satu strategi dalam pengendalian malaria. Penelitian ini bertujuan untuk menggambarkan endemisitas malaria secara spasial di Kabupaten Banyumas tahun 2009-2018 dan dikaitkan dengan kondisi lingkungan. Penelitian ini adalah kuantitatif menggunakan pendekatan spasial deskriptif. Data yang dikumpulkan merupakan data sekunder yang diperoleh dari berbagai sumber yaitu Dinas Kesehatan, Badan Pusat Statistik, Badan Perencanaan Pembangunan, Penelitian dan Pengembangan Daerah (Bappedalitbang) dan Dinas Pekerjaan Umum Kabupaten Banyumas. Analisis data yang digunakan adalah analisis deskriptif yang diolah dengan software ArcGis. Hasil penelitian menunjukan jumlah kasus malaria selama periode 2009-2018 di Kabupaten Banyumas berjumlah 1624 kasus. Persebaran terbanyak di Kecamatan Sumpiuh dan Kecamatan Tambak. Tren Annual Parasite Incidence (API) dari tahun 2009-2018 semakin baik, periode 2009-2012 masih ditemukan kecamatan kategori Moderate Case Incidence (MCI) dan High Case Incidence (HCI), tetapi pada periode tahun 2013-2018 hanya ditemukan kecamatan kategori Low Case Incidence (LCI) saja yaitu Sumpiuh dan Kebasen, selain itu bebas malaria. Hasil analisis spasial menunjukkan sebagian besar kasus malaria berada pada wilayah kategori kepadatan penduduk sedang. Tren persebaran malaria secara spasial di Kabupaten Banyumas sudah semakin baik, walaupun begitu kondisi lingkungan masih berpotensi untuk menularkan malaria.
\end{abstract}

Kata kunci: analisis spasial, malaria, Banyumas

\begin{abstract}
Malaria is still a public health problem in the Banyumas district. Spatial information can be used as a strategy to control malaria. This study aimed to describe malaria cases using spatial analysis in the Banyumas District from 2009 to 2018 based on environmental conditions. This research was quantitative method conducted by a descriptive spatial approach. Data collected by secondary data which was obtained from various sources such as Health Agency, Statistics Indonesia, Indonesian Ministry of National Development, National Institute of Research and Development, and Office of Public Works of Banyumas. The data analysis implemented was descriptive and processed with ArcGis software. The findings illustrated that the number of malaria cases during the 2009-2018 period in Banyumas district was 1624 cases. The most dominant malaria cases distribution were in Sumpiuh and Tambak Subdistrict. The Trend of API from 2009 to 2018 was getting better, 2009 to 2012 found that there were subdistricts with Moderate Case Incidence (MCI) and High Case Incidence (HCI), however, Low Case Incidence (LCI) was present in 2013 to 2018 in Sumpiuh and Kebasen subdistricts and the rests were free from malaria. The results of spatial analysis discovered that most of the malaria cases were in the medium population density area. The distribution of malaria cases has decreased significantly, even though the environmental conditions still potentially transmit malaria.
\end{abstract}

Keywords: spatial analysis, malaria, Banyumas 


\section{PENDAHULUAN}

Malaria masih menjadi masalah kesehatan masyarakat di Indonesia, termasuk di beberapa wilayah di Propinsi Jawa Tengah. Terdapat 6 kabupaten di Jawa Tengah yang masih ditemukan kasus malaria antara lain Kabupaten Purworejo, Banyumas, Kebumen, Purbalingga, Banjarnegara dan Jepara. ${ }^{1}$ Wilayah Kabupaten Banyumas memiliki kondisi topografi dan demografi yang dapat menjadi faktor pendukung persebaran malaria. Iklim dan kondisi lingkungan juga cocok untuk perkembangan nyamuk Anopheles sp. Wilayah perbukitan, persawahan, perkebunan dan pekarangan yang ditumbuhi banyak pohon mendominasi wilayah Kabupaten Banyumas. ${ }^{1}$ Pada tahun 2014 kasus malaria di Kabupaten Banyumas didominasi kasus import (86\%) dan sisanya merupakan kasus indigenous. Hasil kajian mengenai Juru Malaria Desa (JMD) di Kabupaten Banyumas menunjukkan belum maksimal, hal ini terlihat dari masih kurangnya pengetahuan, pemahaman dan ketrampilan JMD dalam menjalankan tugasnya. ${ }^{2}$

Analisis spasial adalah inferensi visual terhadap peta yang merupakan gabungan dari data spasial dan data atribut. Data spasial merujuk pada suatu lokasi atau posisi diatas permukaan bumi. Terdapat 3 kelompok metode analisis spasial yaitu visualisasi, eksplorasi dan modeling. Di bidang kesehatan analisis spasial ini bermanfaat dalam menghubungkan kondisi kewilayahan (kondisi di permukaan bumi) dengan kejadian penyakit. Analisis spasial ini membantu para epidemiolog untuk mendeskripsikan pola spasial penyakit, pengidentifikasi pengelompokkan (clustering) penyakit dan menjelaskan atau memprediksi risiko penyakit. ${ }^{3}$ Analisis ini sebagai alat bantu dalam perumusan kebijakan, pengambilan keputusan, dan atau pelaksanaan kegiatan yang berhubungan dengan kejadian penyakit yang terkait dengan letak suatu obyek dipermukaan bumi.

Pemanfaatan spasial pada penyakit malaria yaitu memberikan metode yang berguna untuk memahami pola spasial epidemi malaria, menilai perubahan dan mengidentifikasi area penularan malaria dan periode epidemi malaria dengan risiko lebih tinggi pada skala yang berbeda. $^{4}$ Studi epidemiologi dengan pendekatan spasial dapat digunakan untuk mengevaluasi terjadinya suatu peristiwa sesuai dengan wilayah geografis serta untuk mengidentifikasi polapola penyebaran penyakit malaria. Hasil pemetaan menggunakan spasial dapat digunakan sebagai acuan dalam pengambilan keputusan, kebijakan dan pelaksanaan kegiatan yang berkaitan dengan eliminasi malaria. $^{5}$

Lingkungan dan perilaku masyarakat berpengaruh besar pada penyebaran malaria. Faktor lingkungan seperti kepadatan penduduk, ketinggian wilayah, curah hujan, pemanfaatan lahan, keberadaan sungai dan jenis batuan diduga berpengaruh pada malaria. Hasil penelitian yang dilakukan di Perbukitan Menoreh menjelaskan kasus malaria lebih banyak terjadi pada wilayah dengan kepadatan penduduk lebih rendah, dekat hulu sungai dan lereng-lereng perbukitan. Kondisi iklim (curah hujan dan kelembaban) dan juga migrasi turut serta berpengaruh pada kejadian malaria di Kabupaten Purworejo. ${ }^{6}$ Ketinggian/letak rumah terbukti berhubungan dengan malaria hasil kajian di Menoreh menunjukkan ketinggian tempat tinggal sebagai faktor risiko malaria. ${ }^{7}$ Adapun nyamuk Anopheles sp. yang berperan sebagi vektor penular malaria di Indonesia juga bervariasi jenisnya. Setiap spesies tersebut menempati topografi yang berbeda. Habitat perindukan vektor malaria ini bisa ditemukan di pantai, pegunungan, perbukitan, persawahan, hutan dan daerah pertambangan. ${ }^{7,8}$ Nyamuk jenis Anopheles sundaicus menularkan malaria di daerah pantai; An. maculatus dan An. aconitus di daerah pegunungan. Di Indonesia bagian timur, nyamuk yang terbukti sebagai vektor malaria adalah An. bancrofti, An. koliensis, An. farauti, An. subpictus, An. barbirostris, An. sundaicus dan An. vagus. Nyamuk yang berperan sebagai vektor malaria di Jawa 
Tengah dan Jawa Timur adalah An. aconitus, An. balabacensis, Anopheles maculatus dan An. sundaicus, sedangkan di Jawa Barat, yaitu An. sundaicus, An. aconitus dan An. balabacensis. ${ }^{9-11}$

Analisis spasial pada Geographic Information System (GIS) dapat digunakan untuk membantu dalam mengidentifikasi wilayah yang berisiko malaria sehingga upaya pengendalian bisa diupayakan. Tujuan penelitian ini adalah memperoleh gambaran kasus malaria dengan pendekatan spasial tahun 2009-2018 di Kabupaten Banyumas.

\section{METODE}

Metode yang digunakan dalam penelitian ini adalah kuantitatif dengan pendekatan spasial deskriptif. Penelitian ini dilakukan untuk memberikan gambaran spasial kasus malaria berdasarkan keadaan lingkungan sekitar tempat tinggal penderita malaria di Kabupaten Banyumas tahun 2009-2018. Data yang dikumpulkan antara lain, jumlah kasus malaria per kecamatan, kasus malaria indigenous/import, kelompok umur, jenis kelamin dan jumlah penduduk per kecamatan 2009-2018, luas wilayah, jumlah penduduk, ketinggian wilayah kecamatan, penggunaan lahan, keberadaan sungai, curah hujan dan jenis nyamuk Anopheles. Penelitian ini menggunakan data sekunder yang diperoleh dari Puskesmas, Dinas Kesehatan, Badan Pusat Statistik, Badan Perencanaan Pembangunan, Penelitian dan Pengembangan Daerah (Bappedalitbang) dan Dinas Pekerjaan Umum. Peta spasial Kabupaten Banyumas diperoleh dari Bappedalitbang Kabupaten Banyumas tahun 2019. Analisis data secara deskriptif dalam bentuk peta dan tabel. Peta yang ditampilkan yaitu peta endemisitas malaria per kecamatan yang dikategorikan menjadi HCI (High Case Incidence), MCI (Moderate Case Incidence), dan LCI (Low Case Incidence). HCI jika API $\geq 5$ per mil, MCI jika API 1-4,9 per mil dan LCI jika API $<1$ per mil. Data kasus malaria selama 10 tahun disajikan secara times series. Kasus malaria disandingkan dengan variabel kepadatan penduduk dalam bentuk peta. Software yang digunakan yaitu ArcGis versi 10.2 .

\section{HASIL}

Kabupaten Banyumas merupakan bagian dari Provinsi Jawa Tengah yang memiliki dataran rendah dengan ketinggian rata-rata $108 \mathrm{mdpl}$, terletak antara $7^{\circ} 15^{\prime} 05^{\prime \prime}$ $7^{\circ} 37^{\prime} 10^{\prime}$ ' Lintang Selatan dan antara $108^{\circ} 39^{\prime}$ $17^{\prime \prime}-109^{\circ} 27^{\prime} 15^{\prime \prime}$ Bujur Timur. Luas wilayah Kabupaten Banyumas, adalah berupa daratan seluas 1.327,59 $\mathrm{km}^{2}$. Kabupaten Banyumas terdiri dari 27 kecamatan, 301 desa dan 30 kelurahan. ${ }^{12}$ Kabupaten Banyumas memiliki iklim tropis basah karena terletak di belahan selatan katulistiwa dan diantara lereng pegunungan jauh dari permukaan pantai atau lautan dengan tekanan rata-rata angin 1.001 mbs, dengan suhu udara berkisar antara $21,4^{\circ} \mathrm{C}$ hingga $30,9^{\circ} \mathrm{C}$. Dalam pelaksanaan pelayanan kesehatan bagi masyarakat Kabupaten Banyumas memiliki 19 rumah sakit dan 39 puskesmas yang tersebar di 27 kecamatan di Kabupaten Banyumas. Berdasarkan data kesehatan dari Dinas Kesehatan Kabupaten Banyumas angka kasus malaria di Kabupaten Banyumas mulai dari tahun 2009 hingga 2018 mengalami penurunan setiap tahunnya. Berikut grafik kasus malaria Kabupaten Banyumas tahun 2009-2018 (Gambar 1). 


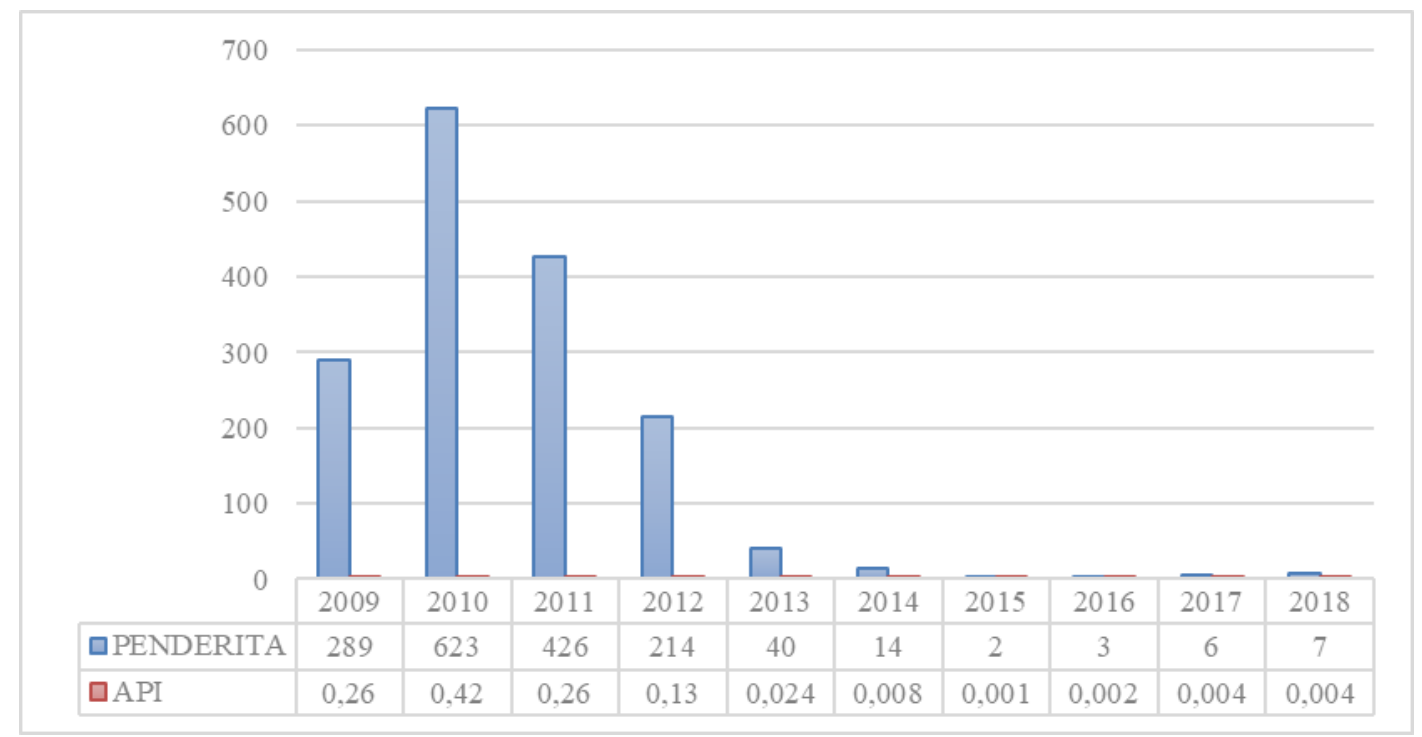

Gambar 1. Kasus Malaria Kabupaten Banyumas Tahun 2009-2018 ${ }^{12}$

Data malaria di Kabupaten Banyumas

Tahun 2009 sampai dengan 2018 menunjukkan bahwa kasus malaria selalu ada setiap tahunnya dan cenderung mengalami penurunan kasus malaria di Kabupaten Banyumas pada tahun 2009-2018 berjumlah 1.624 kasus, dengan terbanyak dari Kecamatan Sumpiuh, Tambak dan Kemranjen. Berikut ini disajikan gambaran kasus malaria di Kabupaten Banyumas tahun 2009-2018.

\section{Karakteristik Malaria}

Berdasarkan karakteristik umur, menunjukkan sebagian besar kasus malaria di
Kabupaten Banyumas periode 2010-2018 terjadi pada kelompok umur 15-54 tahun (63\%) dan terendah pada kelompok umur 0-11 bulan (1\%). Distribusi penderita ini paling banyak di Kecamatan Sumpiuh, Tambak dan Kemranjen (Gambar 2). Data umur dan jenis kelamin pada tahun 2009 tidak diketahui pengkategoriannya sehingga tidak disajikan. Berdasarkan jenis kelamin, jumlah kasus malaria di Kabupaten Banyumas tahun 20102018 adalah proporsi laki-laki sebanyak 826 (62\%) dan sisanya perempuan 509 (38\%) (Gambar 3). 


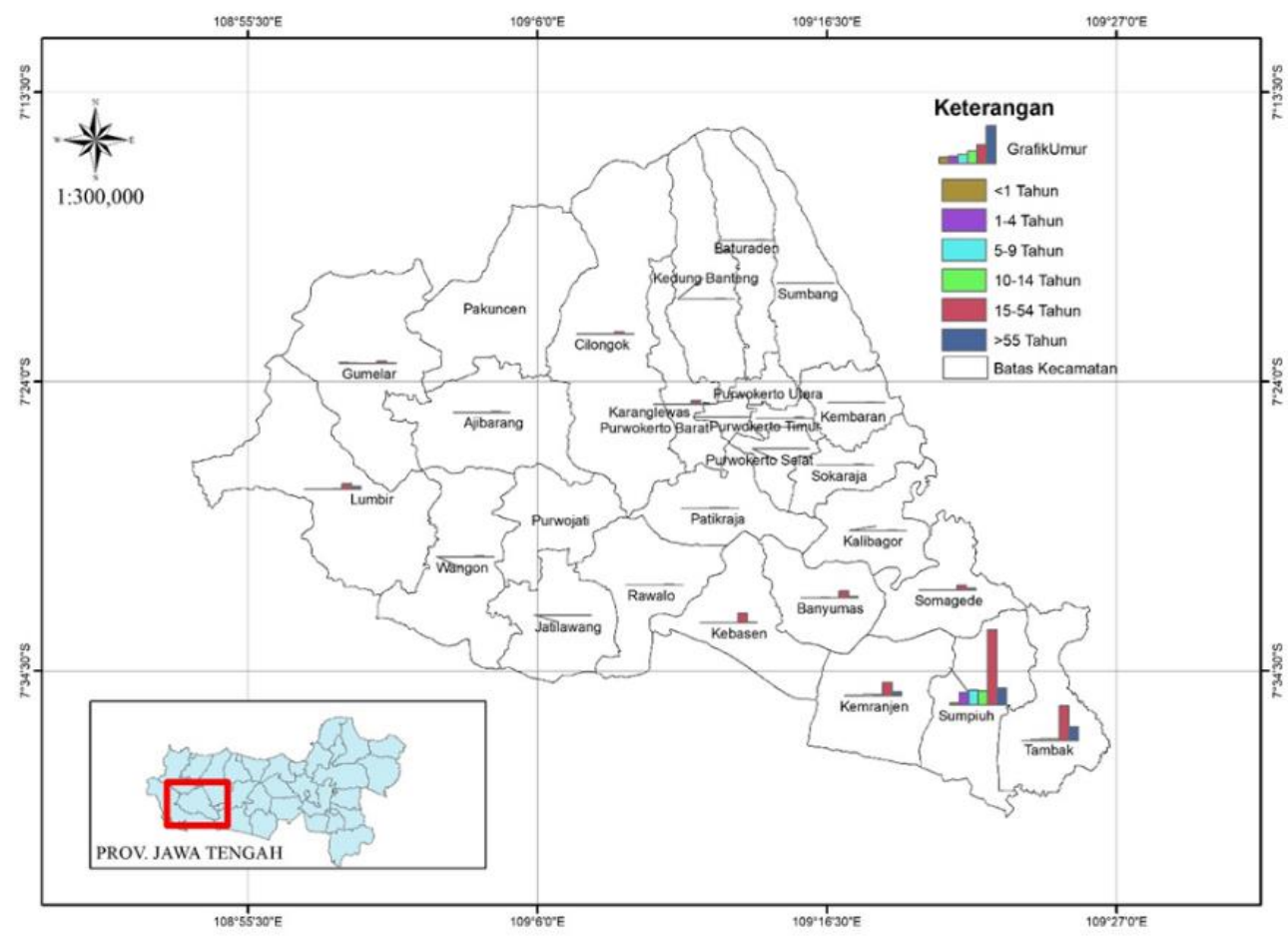

Gambar 2. Distribusi Kasus Malaria Per Kecamatan Berdasarkan Kelompok Umur di Kabupaten Banyumas Tahun 2010-2018

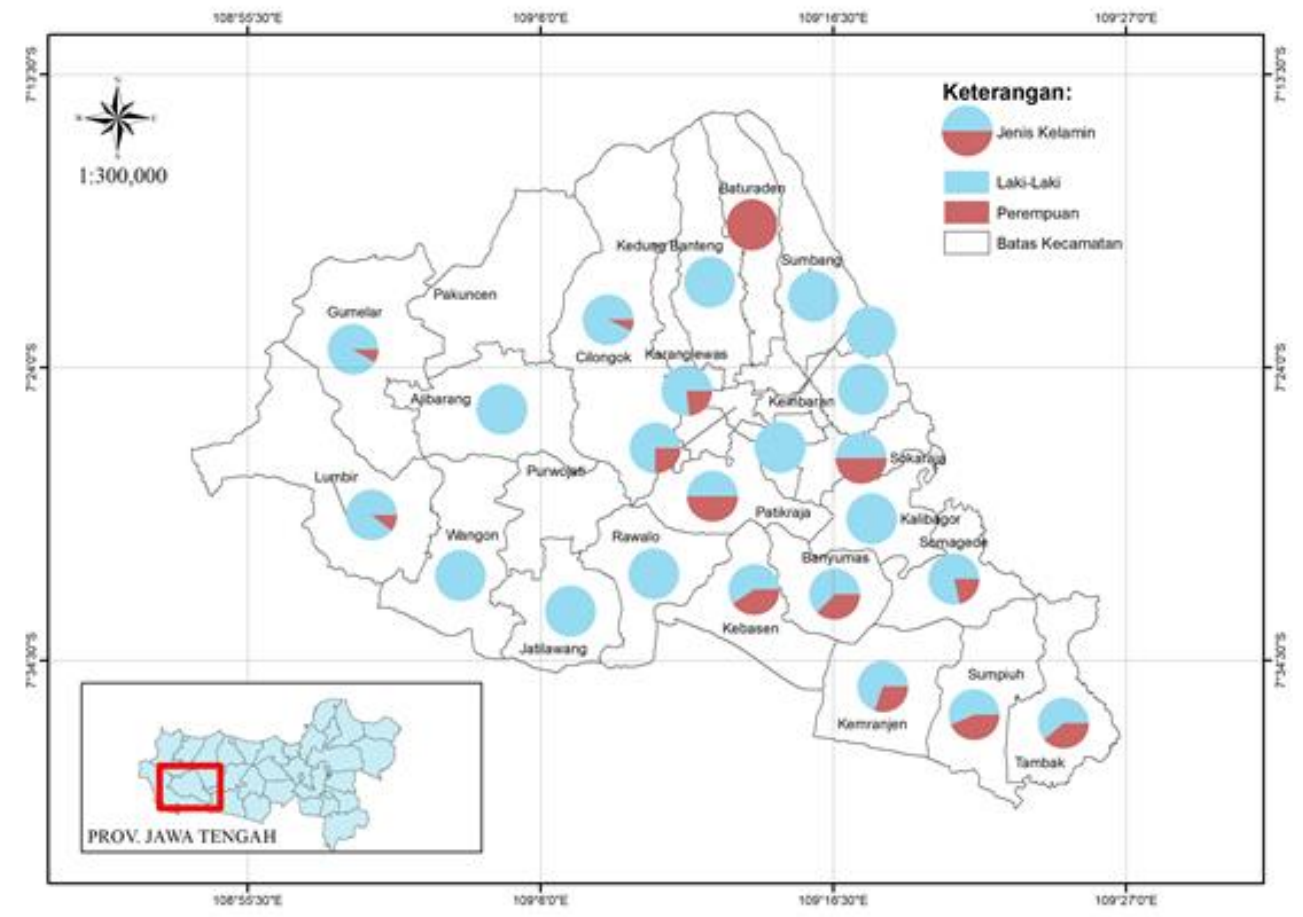

Gambar 3. Distribusi Kasus Malaria Per Kecamatan Berdasarkan Jenis Kelamin di Kabupaten Banyumas Tahun 2010-2018 
Berikut ini dijabarkan jumlah kumulatif kasus malaria yang dilaporkan selama periode 2009-
2018 di Kabupaten Banyumas disajikan pada Tabel 1.

Tabel 1. Karakteriksik Malaria di Kabupaten Banyumas tahun 2009-2018

\begin{tabular}{|c|c|c|c|c|c|c|c|c|c|c|}
\hline \multirow{2}{*}{$\begin{array}{l}\text { Karakteristik } \\
\text { Malaria }\end{array}$} & \multicolumn{10}{|c|}{ TAHUN } \\
\hline & 2009 & 2010 & 2011 & 2012 & 2013 & 2014 & 2015 & 2016 & 2017 & 2018 \\
\hline Total kasus & 289 & 623 & 426 & 213 & 40 & 14 & 3 & 3 & 6 & 7 \\
\hline Import & 23 & 97 & 80 & 32 & 21 & 12 & 1 & 3 & 6 & 7 \\
\hline Indigenous & 266 & 526 & 346 & 182 & 19 & 2 & 1 & 0 & 0 & 0 \\
\hline Kematian & 3 & 5 & 0 & 0 & 0 & 0 & 0 & 0 & 0 & 0 \\
\hline CFR & 1.038 & 0.802 & 0 & 0 & 0 & 0 & 0 & 0 & 0 & 0 \\
\hline
\end{tabular}

Kasus malaria semakin berkurang jumlahnya dari tahun ke tahun, tetapi setiap tahun selalu dilaporkan adanya kasus malaria import. Jumlah malaria indigenous ditemukan tahun 2009-2015, dengan jumlah yang semakin menurun. Mulai tahun 2016 tidak dilaporkan lagi adanya kasus malaria indigenous di Kabupaten Banyumas. Kejadian kematian akibat malaria hanya terjadi pada tahun 2009 dan 2010 saja, dengan CFR sekitar $1 \%$.

\section{Endemisitas Malaria (Annual Parasite Incidence)}

Endemisitas malaria dikategorikan menjadi HCI (High Case Incidence), MCI (Moderate Case Incidence), LCI (Low Case Incidence) dan bebas malaria. Status endemisitas malaria di Kabupaten Banyumas menunjukkan pada periode tahun 2009-2012 masih diketemukan kecamatan kategori MCI dan HCI, tetapi pada periode tahun 2013-2018 hanya diketemukan kecamatan kategori LCI saja. Pada tahun 2009 Kecamatan Sumpiuh termasuk ketegori HCI dan Kecamatan Tambak kategori MCI. Kondisi ini masih sama sampai tahun 2012, dimana ada 3 kecamatan yang berbatasan yang termasuk kategori $\mathrm{HCI}$ dan MCI, yaitu Kecamatan Sumpiuh, Tambak dan Kemranjen. Beberapa wilayah Kabupaten Banyumas hanya termasuk kategori kecamatan LCI saja mulai tahun 2013-2018. Pada tahun 2018 hanya ada 2 kecamatan dengan ketegori LCI yaitu Kecamatan Sumpiuh dan Kebasen. Berikut ini peta endemisitas malaria di Kabupaten Banyumas tahun 2009-2018 (Gambar 4). 


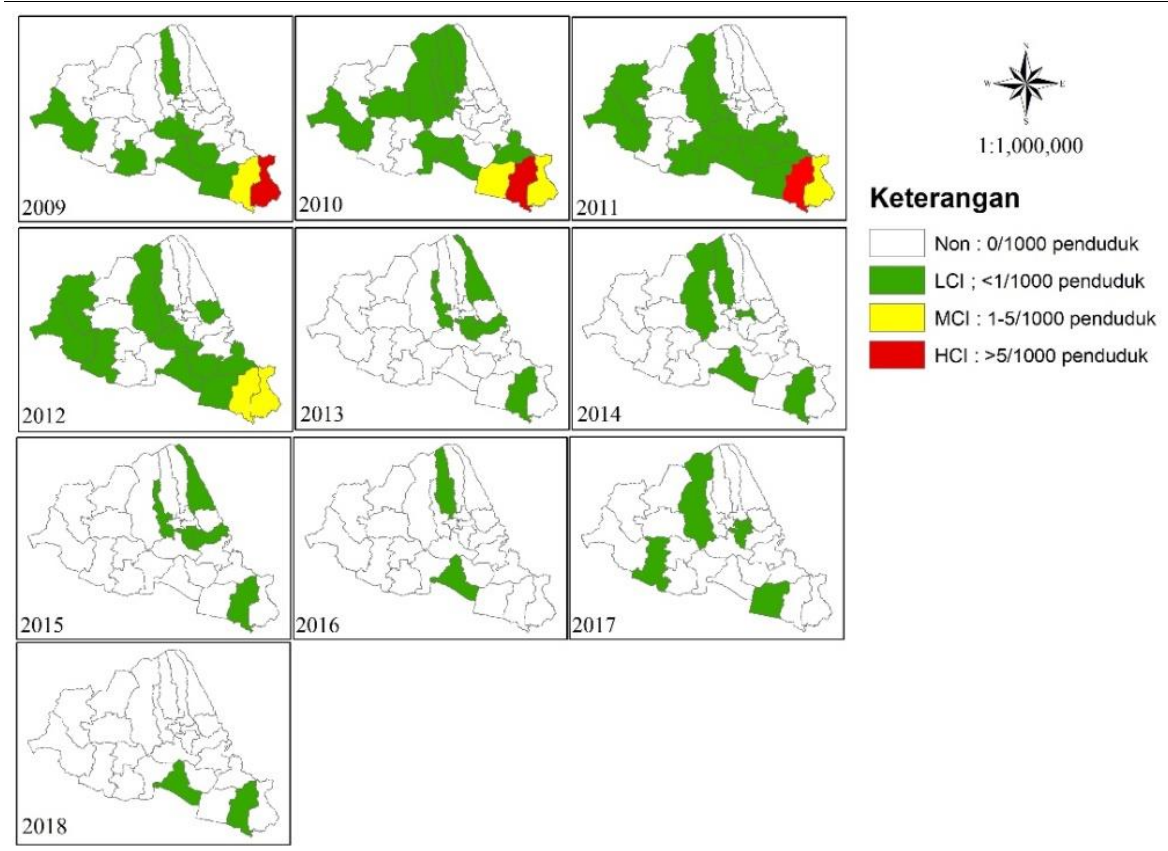

Gambar 4. Endemisitas Malaria Per Kecamatan di Kabupaten Banyumas 2009-2018

\section{Sebaran Malaria Per Kecamatan}

Periode tahun 2009 sampai 2018 dilaporkan ada 1.624 kasus malaria yang didominasi dari wilayah ujung timur selatan Kabupaten Banyumas, yang meliputi Kecamatan Sumpiuh, Tambak, Kemranjen, Kebasen dan Banyumas.
Tahun 2010 merupakan tahun dimana jumlah kasus malaria terbanyak, dengan dilaporkan 623 kasus $(38,4 \%)$, kemudian tahun 2011 sebanyak 426 kasus (26,2\%). Berikut ini sebaran kasus malaria disajikan dalam peta (Gambar 5).

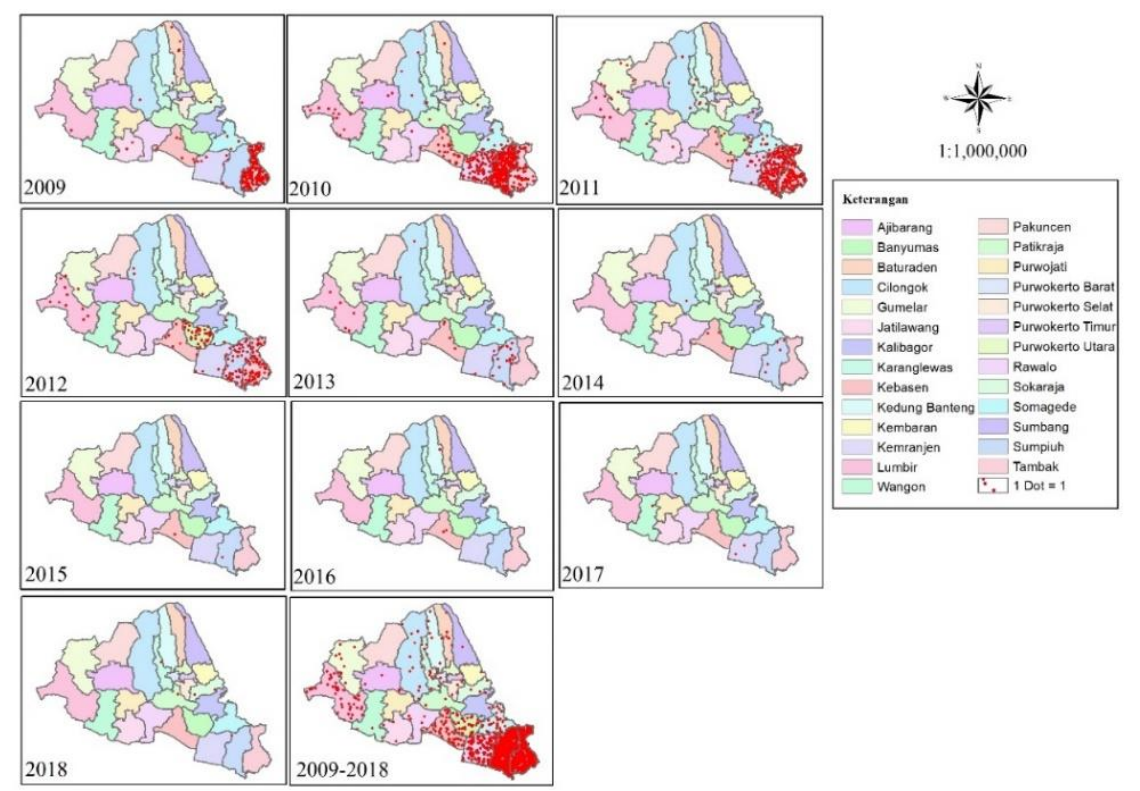

Gambar 5. Peta Sebaran Kasus Malaria Per Kecamatan di Kabupaten Banyumas Tahun 2009-2018 


\section{Malaria dengan Kepadatan Penduduk}

Pada tahun 2009 tidak didapatkan data kepadatan penduduk, sehingga overlay kepadatan penduduk dengan kasus malaria hanya disajikan pada tahun 2010-2018 (Gambar 6). Hasil overlay menunjukkan kasus malaria berada pada wilayah dengan ketegori kepadatan sedang dan rendah. Sangat jarang ditemukan kasus malaria pada wilayah dengan kepadatan penduduk tinggi. Pada tahun 20172018 kasus malaria terjadi di wilayah yang tinggi kepadatan penduduknya dan semua kasus merupakan malaria import.
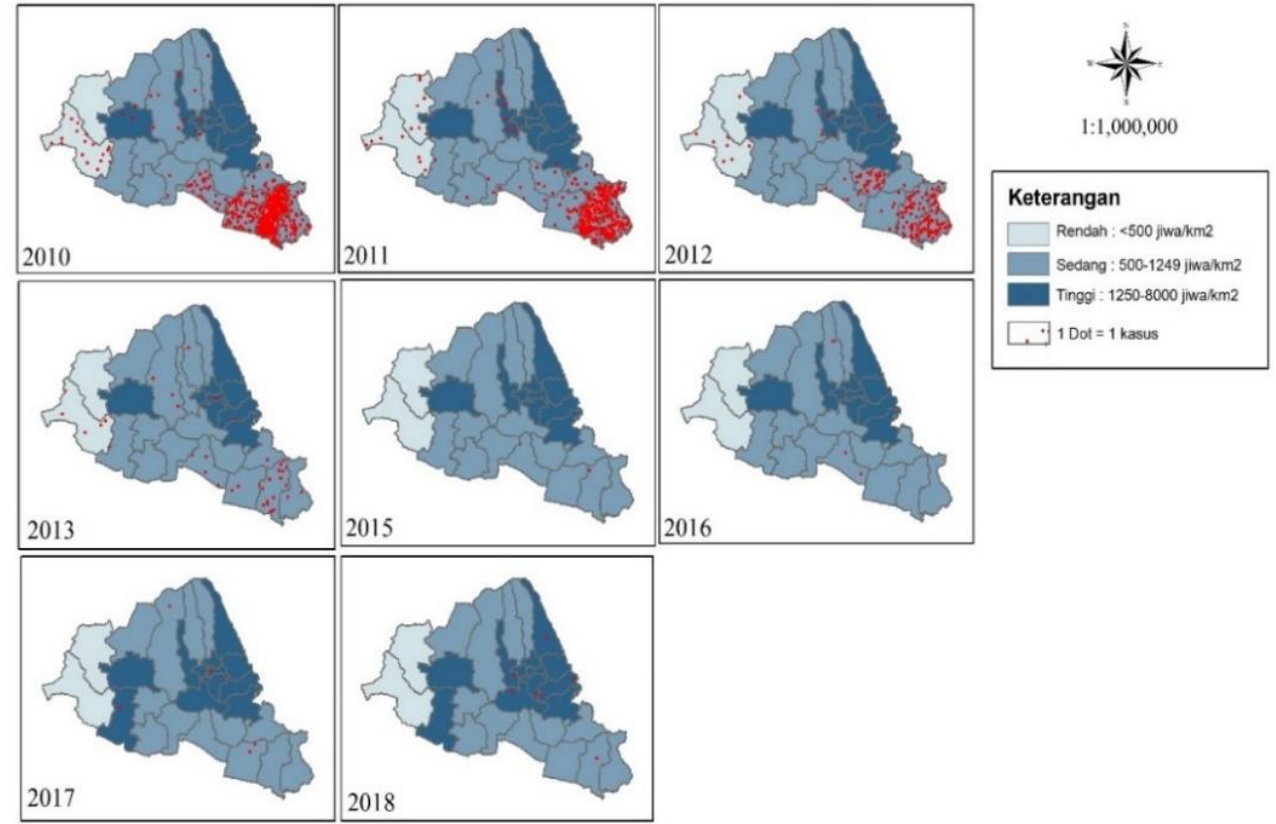

Gambar 6. Peta Kepadatan Penduduk dan Sebaran Malaria di Kabupaten Banyumas Tahun 2010-2018

\section{PEMBAHASAN}

Selama periode tahun 2009 sampai 2018 dilaporkan 1.624 kasus malaria di Kabupaten Banyumas, dengan persentase lebih banyak pada laki-laki. Jenis kelamin ini terkait dengan jenis pekerjaan, laki-laki lebih banyak beraktivitas di luar rumah. Penduduk di Kabupaten Banyumas sebagian besar bekerja sebagai petani, banyak aktivitas dilakukan di luar rumah, kadang juga dilakukan malam hari. Pekerjaan di bidang pertanian mempunyai resiko lebih besar kontak dengan vektor malaria seperti kebiasaan saat bermukim di area pertanian pada musim bertanam dan menjaga aliran air supaya lancar. ${ }^{13,14}$ Usia penderita malaria sebagian besar merupakan usia produktif. Hasil ini sesuai dengan studi di India yang menyatakan kelompok umur 30-60 tahun merupakan kelompok berisiko malaria. ${ }^{14}$ Hal ini terkait dengan banyaknya aktivitas di luar rumah pada usia produktif.

Tren endemisitas malaria (API) dari tahun 2009 sampai 2018 menunjukkan perkembangan yang lebih baik, semakin sedikit kecamatan masuk dalam ketegori LCI, bahkan mulai tahun 2016 hanya ditemukan kasus malaria import saja. Jumlah kasus malaria indigenous juga semakin sedikit, hal ini menunjukkan program pengendalian malaria sudah berhasil dilaksanakan di Kabupaten Banyumas. Berbagai upaya pengendalian malaria sudah dilakukan di Kabupaten Banyumas, antara lain pembagian kelambu berinsektisida, penemuan penderita dengan cepat dan segera melakukan pengobatan, dan surveilans epidemiologi. ${ }^{1,2}$ Kombinasi metode penyemprotan insektisida 
dengan pemakaian kelambu menunjukkan hasil yang lebih baik dalam mengurangi kejadian malaria jika dibandingkan hanya menggunakan satu metode saja. ${ }^{14}$ Berbagai upaya juga dapat dilakukan oleh masyarakat untuk mencegah gigitan nyamuk, antara lain menggunakan repellent, obat anti nyamuk, tanaman pengusir nyamuk dan pakaian panjang sebagai pelindung. ${ }^{13}$ Walaupun begitu dengan masih dilaporkan adanya laporan kasus malaria import di Kabupaten Banyumas setiap tahun menunjukkan surveilans migrasi harus selalu ditingkatkan. Pada saat banyak pendatang masuk ke wilayah Banyumas, misalnya saat lebaran atau adanya acara adat yang menyebabkan tradisi mudik terjadi, maka semua harus waspada terhadap kemungkinan terjadinya kasus malaria, karena di wilayah Kabupaten Banyumas masih ditemukan vektor yaitu An. flavirostris, An. maculatus, dan An. barbirostris. Tempat perkembangbiakan jentik nyamuk tersebut antara lain kobakan di sepanjang sungai, kolam di sepanjang kebun, dan kolam tempat perendaman kayu. ${ }^{15}$ Studi lain di Kabupaten Banyumas menemukan spesies An. aconitus, An. maculatus dan An. balabacencis. Nyamuk ini banyak mengigit dan istirahat di luar rumah. Sebagian besar kejadian malaria tersebar di dekat sungai dan semak belukar. ${ }^{16}$ Terdapat 3 kecamatan yang membutuhkan perhatian dalam pengendalian malaria yaitu Kecamatan Sumpiuh, Tambak dan Kemranjen. Ketiga kecamatan ini saling berbatasan satu dengan lainnya. Kondisi alam mendukung terjadinya penularan malaria di 3 kecamatan ini. Kondisi banyak hutan, sawah dan sungai-sungai kecil di daerah ini juga berpotensi menjadi perindukan nyamuk malaria. Faktor-faktor yang mendukung sebagai tempat perkembangbiakan vektor malaria seperti sungai, genangan air, mata air, sawah dengan irigasi non teknis, dan tentu saja perilaku masyarakat. Hasil studi di Perbukitan Menoreh menunjukkan kejadian malaria banyak ditemukan di daerah perbukitan dengan banyak ditemukan sungai, mata, kalen, cekungan/kobakan air yang menjadi perindukan nyamuk. $^{7}$
Hasil analisis overlay malaria dengan kepadatan penduduk menunjukkan malaria banyak terjadi pada wilayah ketegori kepadatan sedang dan rendah. Hasil ini sesuai dengan penelitian Rejeki et al tahun 2018 yang menyatakan ada hubungan kepadatan penduduk dengan kejadian malaria, malaria lebih banyak terjadi pada wilayah dengan kepadatan penduduk rendah. ${ }^{7}$ Wilayah perkotaan dengan kepadatan penduduknya tinggi sebagian besar merupakan wilayah yang tidak cocok untuk vektor malaria karena kurangnya tempat berkembangbiak dan terjadinya pencemaran pada habitat larva. ${ }^{7} \mathrm{Di}$ Papua kejadian malaria juga lebih banyak terjadi di daerah rural dibanding derah urban. Di daerah rural yang lebih sedikit kepadatan penduduknya ini banyak ditemukan tempat perindukan nyamuk berupa sungai-sungai dan kobakan kobakan. ${ }^{17}$

Suhu udara dapat mempengaruhi perkembang biakan nyamuk Anopheles sp. ${ }^{18}$ Suhu yang hangat atau lebih tinggi akan memperpendek durasi siklus ekstrinsik sehingga nyamuk akan lebih cepat infektif dan penyebaran akan semakin luas. ${ }^{19}$ Temperatur yang cocok untuk kehidupan nyamuk yaitu 16$36^{\circ} \mathrm{C}$ dengan keberlangsungan hidup $90 \%$. Proporsi tertinggi untuk keberlangsungan masa inkubasi nyamuk adalah pada suhu $28-32^{\circ} \mathrm{C} .{ }^{20}$

Vektor malaria bersifat lokal spesifik. Setiap daerah mempunyai karakteristik vektor yang berbeda. Hasil survei tempat perkembangbiakan di Kabupaten Banyumas diperoleh beberapa tipe tempat perkembangbiakan malaria berupa kobakankobakan di sekitar sungai, kolam, kolam dengan rendaman kayu, serta kobakan yang digunakan sebagai tempat rendaman kayu. Pada kobakan di sepanjang sungai ditemukan An. flavirostris, An. maculatus, dan Culex fragilis. Pada kolam ditemukan $A n$. barbirostris, An. flavirostris dan $C x$. quinquefasciatus. Pada tempat perindukan berupa kolam dengan rendaman kayu terdapat An. barbirostris dan Culex sp. Sedangkan pada kobakan yang digunakan untuk rendaman kayu hanya ditemukan $C x$. quinquefasciatus. ${ }^{15}$ 
Di sekitaran sungai juga banyak ditemukan habitat jentik nyamuk Anopheles sp, yang berada di bongkahan batu-batu dipinggiran sungai. ${ }^{7}$ Sungai menjadi tempat berkembangbiak nyamuk dikarenakan sungai dapat dijadikan habitat vektor sepanjang tahun. ${ }^{21}$ Di sungai banyak ditemukan jenis bantuan yang bisa mendukung menjadi perindukan vektor. Jenis batuan aluvial memiliki potensi untuk mendukung terjadinya persebaran malaria dikarenakan adanya penambangan batuan yang menyebabkan terjadinya lubang, apabila turun hujan menjadi genangan air untuk perkembangbiakan nyamuk Anopheles sp. ${ }^{22}$ Studi di Menoreh menunjukkan malaria lebih banyak terjadi pada wilayah dengan jenis batuan andesit, andesit tua, dan formasi Bemmelentio dengan topografi yang kasar dan memiliki porositas rendah. Porositas rendah ini yang memungkinkan terjadinya akumulasi genangan air pada singkapan batu, sehingga bisa menjadi tempat perindukan nyamuk. ${ }^{23}$

\section{KESIMPULAN}

Status endemisitas malaria di Kabupaten Banyumas dari tahun 2009 sampai 2018 semakin membaik, pada periode tahun 2009-2012 masih diketemukan kecamatan kategori MCI dan HCI, tetapi pada periode tahun 2013-2018 hanya diketemukan kecamatan kategori LCI saja. Pada tahun 2018 terdapat 2 kecamatan dengan kategori LCI yaitu Sumpiuh dan Kebasen, selain itu bebas malaria. Kasus malaria lebih banyak berada pada wilayah dengan ketegori kepadatan penduduk kategori sedang dan rendah.

\section{SARAN}

Kewaspadaan dini selalu diterapkan pada wilayah-wilayah berisiko malaria secara spasial. Perlu dilakukan pemetaan endemisitas per desa/dusun di Kecamatan Sumpiuh dan Kebasen sehingga dapat diketahui prioritas desa/dusun yang masih bermasalah dengan malaria untuk dapat dilakukan intervensi pengendalian yang lebih spesifik.

\section{KONTRIBUSI PENULIS}

Kontribusi setiap penulis dalam artikel ini adalah DSSR dan DD sebagai kontributor utama bertanggung jawab dalam konsep penulisan artikel secara menyeluruh. SR kontributor anggota bertanggung jawab dalam analisis data.

\section{UCAPAN TERIMA KASIH}

Ucapan terima kasih kepada Dinas Kesehatan, Badan Pusat Statistik, Badan Perencanaan Pembangunan, Penelitian dan Pengembangan Daerah (Bappedalitbang) dan Dinas Pekerjaan Umum Kabupaten Banyumas yang sudah menyediakan data untuk penelitian ini. Juga kepada LPPM Unsoed atas pendanaan untuk skim penelitian institusi.

\section{DAFTAR PUSTAKA}

1. Rejeki DSS, Sari RA, Nurhayati N. Annual parasite incidence malaria di Kabupaten Banyumas. Kesmas: National Public Health Journal. 2014;9(2):137-43. doi: 10.21109/kesmas.v9i2.509.

2. Rejeki DSS, Nurlaela S, Octaviana D, Kusnanto H, Murhandarwati EH. Malaria community health workers eliminating malaria in Banyumas regency. Kemas. 2016;12(1):909. doi: 10.15294/kemas.v12i1.4030.

3. Pfeiffer D, Robinson T, Stevenson M, Stevens $\mathrm{K}$, Rogers D, Clements A. Spatial analysis in epidemiologi. New York: Oxford University Press; 2008.

4. Supriyanto, Nurhayati N, Rejeki DSS. Analysis of malaria incidence in Banyumas using spatio-temporal approach. Kemas. 2017;13(1):1-6. doi: 10.15294/kemas.v13i1.7602.

5. Rejeki DSS, Fuad A, Widartono BS, Murhandarwati EEH, Kusnanto $\mathrm{H}$. Spatiotemporal patterns of malaria at crossboundaries area in Menoreh Hills, Java, Indonesia. Malaria Journal. 2019;18(80):1-12. doi:10.1186/s12936-019-2717-y.

6. Rejeki DSS, Nurhayati N, Aji B, Murhandarwati EEH, Kusnanto H. A time series analysis: weather factors, human migration and malaria cases in endemic area of Purworejo, Indonesia, 2005-2014. Iran J Public Health. 2018;47(4):499-509. 
7. Rejeki DSS, Murhandarwati EEH, Kusnanto H. Analisis spatial malaria di ekosistem perbukitan menoreh: studi kasus malaria bulan September-Desember 2015. KesMas: Jurnal Fakultas Kesehatan Masyarakat. 2018, 12(2):120-32. doi:10.12928/kesmas.v12i2.10828.

8. Hakim L. Faktor risiko penularan malaria di Jawa Barat (kajian epidemiologi tentang vektor, parasit plasmodium dan lingkungan sebagai faktor risiko malaria). Aspirator. 2010;2(1):45-54.

9. Ndoen E, Wild C, Dale P, Sipe N, Dale M. Relationships between anopheline mosquitoes and topography in West Timor and Java, Indonesia. Malaria Journal. 2010;9(242). doi:10.1186/1475-2875-9-242.

10. Sunaryo. Surveilans vektor malaria di Desa Aneka Marga, Kecamatan Rorowatu Utara, Kabupaten Bombana, Provinsi Sulawesi Tenggara. BALABA. 2010;6(2):12-6.

11. Munif A. Nyamuk vektor malaria dan hubungannya dengan aktivitas kehidupan manusia di Indonesia. Aspirator. 2009;1(2):94-102.

12. Badan Pusat Statistik. Profil Kesehatan Kabupaten Banyumas tahun 2019. Purwokerto: Badan Pusat Statistik Kabupaten Banyumas; 2019.

13. Lerebulan N, Bawotang J, Rottie J. Hubungan kebiasaan masyarakat Desa Tumbur dengan kejadian malaria di wilayah kerja Puskesmas Wertamrian Kabupaten Maluku Tenggara Barat. Jurnal Keperawatan. 2013;1(1):1-9.

14. Sharma RK, Singh MP, Saha KB, Bharti PK, Jain V, Singh PP, et al. Socio-economic \& household risk factors of malaria in tribal areas of Madhya Pradesh, central India. Indian J Med Res. 2015;141(5):567-75. doi: 10.4103/0971-5916.159515.

15. Setiyaningsih R, Alfiah S, Garjito TWA, Heriyanto B. Assesment penyakit tular vektor malaria. Media Litbangkes.2015;25(2):1-6.
16. Yani F, Satoto TBT. aktor risiko kejadian malaria dan pemetaan pola sebaran vektor pada desa endemis malaria di Kabupaten Banyumas Propinsi Jawa Tengah Tahun 2012 [Tesis]. Yogyakarta: Fakultas Kedokteran UGM; 2013. Diunduh dari https://repository.ugm.ac.id/id/eprint/126529.

17. Hanandita W, Tampubolon G. 2016. Geography and social distribution of malaria in Indonesian Papua: a cross-sectional study. Int J Health Geogr. 2016;15(13). doi: 10.1186/s12942-016-0043-y.

18. Susanna D. Dinamika penularan malaria. Jakarta: UI-Press; 2010.

19. Wangdi K, Singhasivanon P, Silawan T, Lawpoolsri S, White NJ, Kaewkungwal J. Development of temporal modelling for forecasting and prediction of malaria infections using time-series and ARIMAX analyses: a case study in endemic districts of Bhutan. Malaria Journal. 2010;9(251):1-9. doi: $10.1186 / 1475-2875-9-251$

20. Alemu A, Abebe G, Tsegaye W, Golassa L. Climatic variables and malaria transmission dynamics in Jimma town, South West Ethiopia. Parasites \& Vectors. 2011;4(30). doi:10.1186/1756-3305-4-30.

21. Oesterholt MJAM, Bousema JT, Mwerinde OK, Harris C, Lushino P, Masokoto A, et al. Spatial and temporal variation in malaria transmission in a low endemicity area in northern Tanzania. Malaria Journal. 2006;5(98):1-7. doi: 10.1186/1475-2875-5-98.

22. Castellanos A, Chaparro-Narváez P, MoralesPlaza CD, Alzate A, Padilla J, Arévalo M, et al. Malaria in gold mining areas in Colombia. Mem Inst Oswaldo Cruz.. 2016;111(1):59-66. doi: 10.1590/0074-02760150382.

23. Murhandarwati EEH, Fuad A, Sulistyawati, Wijayanti MA, Bia MB, Widartono BS, et al. Change of strategy is required for malaria elimination: a case study in Purworejo District, Central Java Province, Indonesia. Malaria Journal. 2015;14(318):11-4. doi:10.1186/s12936-015-0828-7. 
BALABA Vol. 16 No. 2, Desember 2020: 169-180 